\title{
Analysis of Service Quality Towards Patient Satisfaction (Comparative Study of Patients Using Telemedicine Application and Face to Face Consultation in Healthcare)
}

\author{
Tamara Tantarto, Dadang Kusnadi, and Hadyana Sukandar
}

\begin{abstract}
The world today knows the use of technology in more areas of life than ever. The invention of health technology enables health workers to utilize telecommunication devices in delivering care, easing access to healthcare anywhere, anytime. Telemedicine Application is one of the rapidly developing health applications in Indonesia. This study aimed to analyze the association between quality of services, including tangibility, reliability, responsiveness, assurance, and empathy, and patient satisfaction in Telemedicine Application users compared to conventional health services (face-to-face). Primary data were obtained from 100 respondents who had received healthcare either from Telemedicine Application or face-to-face (conventional) throughout 2019. Data analysis used path analysis and the Wilcoxon test. This study found that service quality, both in Telemedicine Application and conventional care, influenced patient satisfaction. In subjects using Telemedicine Application, reliability and responsiveness did not significantly influence patient satisfaction. Whereas in patients receiving conventional care, tangibility, responsiveness, and empathy were not significantly influential to patient satisfaction. Conventional patient satisfaction is significantly higher compared to Telemedicine Application patient satisfaction.
\end{abstract}

Index Terms - service quality, patient satisfaction, Telemedicine Application, conventional.

\section{INTRODUCTION AND RESEARCH OBJECTIVES}

\section{A. Introduction}

Today's world is filled with the widespread use of technology in various areas of life. In this fast-paced digital era, technological innovation also touches the field of health services, which ultimately presents the existence of nonformal health institutions that grow upon the advances in information technology.

In the 21 st century, doctors can use mobile devices to download lab results, medical records, medical images, and drug information. In addition, the exchange of information between doctors and patients can also be done only by using mobile devices [1]. A 2011 Canadian study in medical students found that $85 \%$ used mobile devices for information exchange as well as health-related communication due to their flexibility and ability to access information quickly [2]. Meanwhile, according to statistical data in the United States, $75 \%$ of patient-doctor consultation happens remotely using telephone and video call [3].

In Indonesia, the development of telemedicine began in the 90s through a simple device namely the telephone. This development could be considered quite late due to constraints coming from Indonesia's geographical condition of being an archipelago, topped with inadequate infrastructure in remote areas and lack of legal aspects and data security [4].

The legal aspects regarding telemedicine have only been regulated in the Minister of Health of the Republic of Indonesia Regulation number 20 in 2019.

According to the ministerial regulation, telemedicine is the provision of long-distance health services by health professionals using information and communication technology, including sharing information on diagnosis, treatment, prevention of illness and injury, research and evaluation, and continuing education of health service providers for the benefit of improving the health of individuals and the community. Telemedicine services in Indonesia consist of teleradiology, teleelectrocardiography, teleultrasonography, clinical teleconsultation services and other consulting services [5].

On the international scene, several studies have been conducted. In 2001, a Norwegian study compared the satisfaction levels of dermatology patients who had a face-toface consultation with those who did so through telemedicine. The results stated no significant difference in satisfaction because each had its advantages and disadvantages. Telemedicine services provide benefits such as quick diagnosis, shorter overall time, saving money, and reducing stress. However, telemedicine was considered weak in terms of feeling shame when consulting throughout telephone, discomfort, and difficulty in hearing the doctors [6].

A study in the United States compared telemedicine service at home with conventional hospital care and followed both groups for 6 and 12 months. From 369 respondents that fit the criteria, it can be concluded that there is a significant difference in patients' satisfaction between the two groups [7].Another study conducted in the United States with 1,734 respondents concluded that $94-99 \%$ of the study population were highly satisfied with telemedicine service. A third of the respondents preferred telemedicine than face-to-face consultation. Hospitable service and service quality are essential for patients in health service via telemedicine [8].

In 2017, according to the Indonesian Medical Council, the

Published on October 19, 2020.

Tamara Tantarto, Univeritas Padjajaran, Indonesia.

(corresponding e-mail: tamaratantarto31@gmail.com)

Dadang Kusnadi, Univeritas Padjajaran, Indonesia.

Hadyana Sukandar, Univeritas Padjajaran, Indonesia. 
ratio of specialist doctors per 100 thousand Indonesians is still at 14.6, while the target is 10.6. On the other hand, the ratio of general practitioners per 100,000 population is 47.6 , while the target is 43 . The issue of health workers in Indonesia that is still a problem today is the insufficient number and type of health workers, uneven distribution of health personnel, and inadequate quality of health workers. Evenly distributed [9]. Telemedicine is predicted to develop well because it can be accessed anytime and anywhere so that remote areas are reached by health service facilities with the limited distribution of health workers.

In Indonesia, health-based applications are widely available. Telemedicine applications in Indonesia that provide teleconsultation service include:

TABLE 1: TELEMEDICINE APPLICATION IN INDONESIA (STUDY BY AUTHOR, 2019)

\begin{tabular}{|c|c|c|c|c|}
\hline Numb & $\begin{array}{l}\text { Application } \\
\text { Name }\end{array}$ & $\begin{array}{c}\text { Year } \\
\text { Founded }\end{array}$ & Founder & $\begin{array}{c}\text { Valuation } \\
\text { (Reference: } \\
\text { tracxn) }\end{array}$ \\
\hline 1 & Klikdokter & 2008 & $\begin{array}{l}\text { Doddy } \\
\text { Partomihardjo }\end{array}$ & - \\
\hline 2 & MeetDoctor & 2011 & & $\begin{array}{l}480 \\
\text { thousand } \\
\text { US \$ }\end{array}$ \\
\hline 3 & Temenin & 2014 & $\begin{array}{l}\text { Indonesia } \\
\text { Health Ministry }\end{array}$ & - \\
\hline 4 & Alodokter & 2014 & $\begin{array}{l}\text { Nathanael } \\
\text { Faibis }\end{array}$ & $\begin{array}{l}19 \text { million } \\
\text { US \$ }\end{array}$ \\
\hline 5 & $\begin{array}{l}\text { Telemedicine } \\
\text { Application }\end{array}$ & 2016 & $\begin{array}{l}\text { Jonathan } \\
\text { Sudharta }\end{array}$ & $\begin{array}{l}100 \text { million } \\
\text { US \$ }\end{array}$ \\
\hline 6 & Medika App & 2016 & Danang Firdaus & - \\
\hline
\end{tabular}

Telemedicine Application is an application with highest value even though it is the most recently founded, compared to its competitor. The author chose Telemedicine Application as a health-based application to be researched because it has "Chat with a doctor feature" and also "Buy Medicine feature", so the drugs prescribed/recommended by the doctor can be directly obtained by the patients. These features are similar to face-to-face consultation experienced by the patients if they go to healthcare facilities, which include consultation, drug prescription by the doctor, and patient obtain the drugs. For that reason, the author sees Telemedicine Application comparable with face-to-face consultation.

In Indonesia, the lack, or even the absence, of research comparing service quality between face-to-face consultation and via telemedicine, increases the author's interest in doing this research. The novelty of this research, compared to other studies, is the author intends to compare patients' satisfaction between face-to-face consultation to Telemedicine Application experience. The study population is respondents that have experienced both face-to-face consultation and Telemedicine Application service in the same year.

\section{B. Research Objectives}

The purpose of this study is to determine the quality of service and satisfaction of patients using the Telemedicine Application and patients who consult face-to-face, and to analyze the effect of service quality which includes tangible, reliability, responsiveness, assurance, and empathy on patient satisfaction using the Telemedicine Application, and also analyze the differences in satisfaction of patients who consult face to face using the Telemedicine Application.

\section{LITERATURE REVIEW}

\section{A. Service Quality}

Service quality contributes significantly to creating differentiation, positioning, and competitive strategies to each organization [10]. Service quality is generally defined as customer's assessment that serves as their perception of the services provided [11]. In the health sector, the quality of health service is related to ensuring high-quality service thereby increasing people's expectation in obtaining health services [12].

In assessing service quality, there are five dimensions that are immensely important: reliability, assurance, tangibility, responsiveness, and empathy [13].

\section{1) Tangibility}

This dimension directly shows physical evidence of the service provided by the service provider. In this case, it is usually in the form of physical facilities (hospital/clinic building), physical appearance (of the employees or the application), or equipment (technology used)

\section{2) Reliability}

This dimension shows the service provider's ability to deliver services as promised accurately and reliably. Performance should meet customer's expectation means timeliness, equal services for all customers without mistake, sympathetical manner, and excellent accuracy.

\section{3) Responsiveness}

This dimension shows the willingness of the service provider to help and deliver responsive and accurate service to the customer by giving clear information. Leaving customers waiting without an apparent reason causes negative perception in service quality.

\section{4) Assurance}

The assurance given by the service provider is usually in the form of excellent knowledge, mannerism, security and credibility of employees to foster the trust of the customers to the company.

\section{5) Empathy}

This dimension shows the service provider's ability to give sincere and personalized attention to customers in order to understanding customers' desires. Where a company is expected to have an understanding and have knowledge about customers specifically.

\section{B. Patient Satisfaction}

Customer satisfaction can be used as a thought in an overall assessment of the product, with value measurement obtained through experience and feelings that have been tested by the customers to the product [14]. Another opinion stated customer satisfaction is a way of evaluating thoroughly of customer's perspective on the product, in the form of goods or services, every time [15].

A prospect in the medical field stated that patient satisfaction is an overall assessment given by the patient during the period of care that makes the basis of increasing competitiveness value. Patient satisfaction itself has a positive impact in directing the active role of patients to other customers [16]. 
Hence, it can be concluded that patient satisfaction can improve a health service provider's competitiveness compared to its competitors and provide irreplaceable value to patients, namely satisfaction value. Indicators of patient satisfaction are [17]:

1) Overall patient satisfaction.

2) Desire to repeat purchase.

3) Willingness to recommend.

\section{Framework}

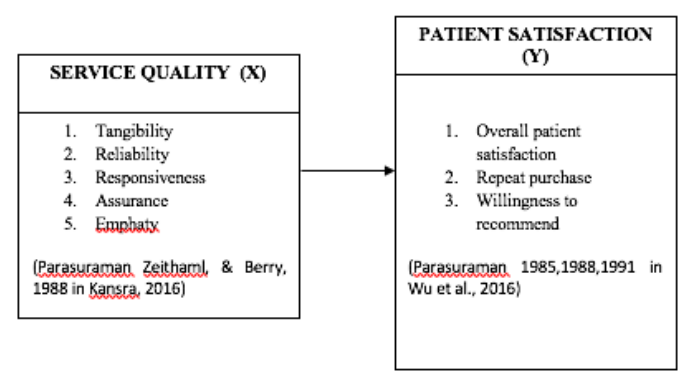

Fig. 1. Study Framework (Study by author, 2019)

\section{Study Hypotheses}

The hypotheses in this study are as follows:

1. There is an influence of service quality on Telemedicine Application's patient satisfaction.

a. There is an influence of tangibility on patient satisfaction.

b. There is an influence of reliability on patient satisfaction.

c. There is an influence of responsiveness on to patient satisfaction.

d. There is an influence of assurance on patient satisfaction.

e. There is an influence of empathy on patient satisfaction.

2. There is an influence of service quality on face-to-face consultation patient satisfaction.

a. There is an influence of tangibility on patient satisfaction.

b. There is an influence of reliability on patient satisfaction.

c. There is an influence of responsiveness on patient satisfaction.

d. There is an influence of assurance on patient satisfaction.

e. There is an influence of empathy on patient satisfaction.

3. There is a significant difference between Telemedicine Application and face-to-face consultation patient satisfaction.

\section{RESEARCH METHODOLOGY}

This study uses a quantitative method with a survey approach. In this study, the survey approach taken was distributing questionnaires. To determine the influence of each variable, this study uses a verification method. This study is also a comparative study because it compares patient satisfaction in both groups of respondents.

This study includes 100 respondents that meet inclusion criteria, which are patients that use both Telemedicine Application and face-to-face consultation in healthcare facility between January - October 2019, aged >18 years old.
Respondents fill in 2 types of questionnaires for Telemedicine Application and conventional service consisting of 20 statements each. Respondents fill out the questionnaire using Likert scale with details as follows: 5 to strongly agree, 4 to agree, 3 to neutral, 2 to disagree, 1 to strongly disagree.

The independent variable $(\mathrm{X})$ in this study is service quality that includes tangibility (X1), reliability (X2), responsiveness (X3), assurance (X4), and empathy (X5). The dependent variable in this study is patient satisfaction.

The instrument used in this study by the author is questionnaires that passed through validity and reliability test. Data from Likert scale are transformed into interval data using 100 Scare formula. Data was then processed using SPSS software version 25.0.

\section{RESUlts AND DisCUSSION}

Of the 100 respondents, the following are the characteristics of the respondents involved in the study:

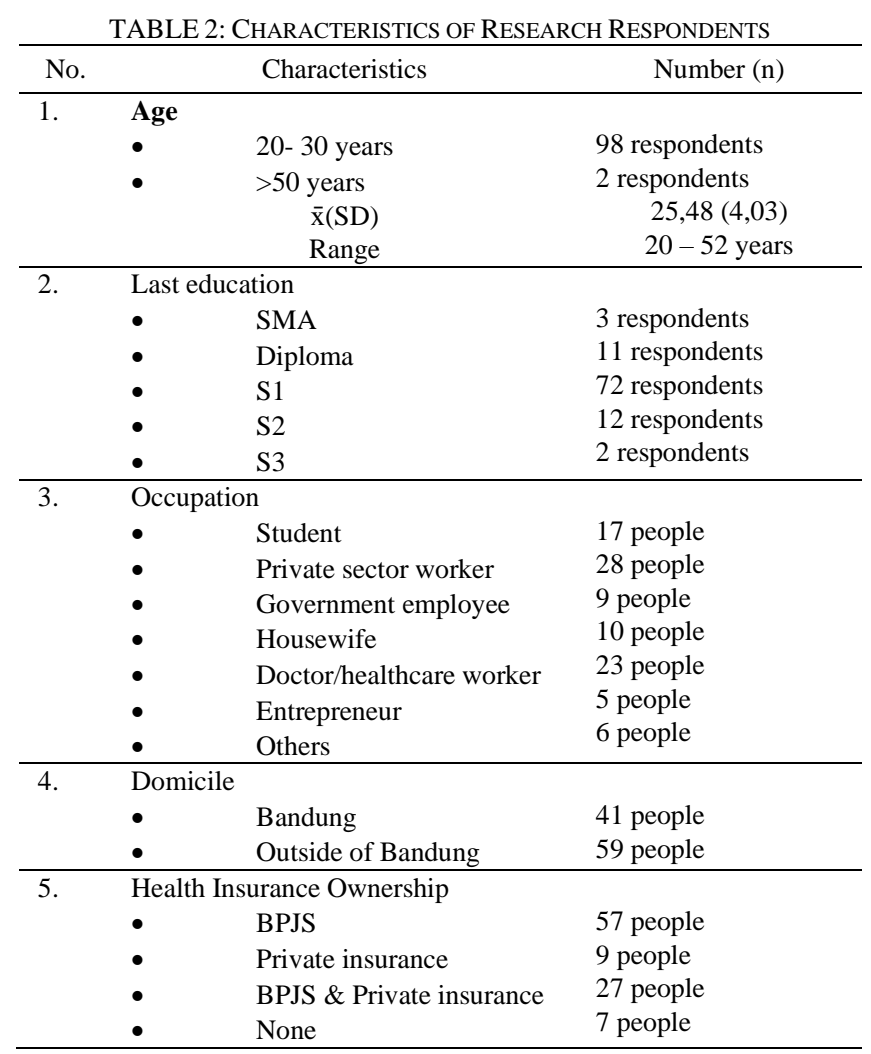

Based on the data above, from age characteristic, the respondents involved in the study is dominantly aged 20-30 years old $(98 \%)$. However, there were still respondents above 50 years old as many as two people that filled out the questionnaires. Based on last education, most respondents were undergraduates $(72 \%)$. The most dominant occupation of the respondents was private employee (28\%), but doctors and other health workers also comprise many respondents (23\%). Most respondents reside outside of Bandung city, as much as $59 \%$. Most respondents have health insurance, be it BPJS or private insurance. Only $7 \%$ of respondents did not have health insurance.

The author made the questionnaire with positive statement items, so Agree and Strongly Agree responses show excellent 
quality and satisfaction. Based on the questionnaire result, $(62.5 \%)$ agree even $(23.5 \%)$ strongly agree that Telemedicine Application service quality is excellent in terms of tangibility. In terms of reliability, (49\%) agree and (13.67\%) strongly agree that Telemedicine Application s reliability is excellent. In terms of responsiveness of Telemedicine Application, (48.67\%) agree and (10.67\%) strongly agree that Telemedicine Application is excellent. Telemedicine Application's service assurance excellence was agreed by $54.75 \%$ and strongly agreed by $12.75 \%$ of the respondents. The empathy aspect of Telemedicine Application's service was agreed by $52.33 \%$, hence there are plenty of respondents who think that doctor's empathy in Telemedicine Application was not excellent. In terms of overall satisfaction, only a little more than half of respondents $(43.40 \%$ agree and $14.40 \%$ strongly agree) that they were satisfied with Telemedicine Application's service. Thus, there were still many people who were not satisfied by Telemedicine Application's service.

Meanwhile, the quality of face-to-face doctor in healthcare facility was agreed to have excellent tangibility because only $19 \%$ of respondents have a neutral opinion. In contrast, others agree that it was excellent. For the reliability aspect, $62.67 \%$ agree and $22.33 \%$ strongly agree that their doctor was excellent. Hence most respondents stated their healthcare service providers were reliable. In terms of responsiveness, only $21 \%$ stated their neutral and disagreeing opinions of conventional service excellence. In terms of assurance aspect, $59.25 \%$ agree and $25.5 \%$ strongly agree that conventional service provides excellent assurance. In terms of empathy, only $21 \%$ were neutral and disagreeing, and the rest thought their conventional service was excellent. In terms of overall satisfaction, only $15.60 \%$ stated they strongly disagree, disagree or neutral, of their conventional healthcare service experience.

H1: There is an influence of service quality on Telemedicine Application's patient satisfaction

TABLE 3: TELEMEDICINE APPLICATION's QuestionNAIRE DATA PROCESS RESULT

\begin{tabular}{ccccc}
\multicolumn{8}{c}{ Model Summary } \\
\hline Model & $\mathrm{R}$ & $R$ Square & $\begin{array}{c}\text { Adjusted } R \\
\text { Square }\end{array}$ & $\begin{array}{c}\text { Std. Error of the } \\
\text { Estimate }\end{array}$ \\
\hline 1 & $.843^{\mathrm{a}}$ & .711 & .695 & 8.84810 \\
\hline
\end{tabular}

Predictors: (Constant), Empathy, Tangibility, Responsiveness, Reliability, Assurance

\begin{tabular}{ccccccc}
\multicolumn{8}{c}{ ANOVA $^{\mathrm{a}}$} \\
\hline \multirow{2}{*}{1} & Model & $\begin{array}{c}\text { Sum of } \\
\text { Squares }\end{array}$ & df & $\begin{array}{c}\text { Mean } \\
\text { Square }\end{array}$ & F & \multirow{2}{*}{ Sig. } \\
\hline & Regression & 18065.602 & 5 & 3613.120 & 46.151 & $.000^{\mathrm{b}}$ \\
& Residual & 7359.148 & 94 & 78.289 & & \\
\hline
\end{tabular}

a. Dependent Variable: Patient Satisfaction

b. Predictors: (Constant), Empathy, Tangibility, Responsiveness, Reliability, Assurance.

Based on the result above, with significance $<0.005$ and $\varepsilon$ value is 0.289 , then Hypothesis 1 can be accepted. This result supports the article written by Garcia [18] that one of the telemedicine patient satisfaction factors was service quality. Aside from service quality, Garcia stated there are a lot of other factors supporting telemedicine patient satisfaction, such as price, information availability, scheduling, consultation duration, accessibility, patient's privacy assurance, technology advancement, management given and patient's recovery.

\begin{tabular}{|c|c|c|c|c|c|c|}
\hline & \multirow{2}{*}{ Model } & \multicolumn{2}{|c|}{$\begin{array}{l}\text { Unstandardized } \\
\text { Coefficients }\end{array}$} & \multirow{2}{*}{$\begin{array}{c}\begin{array}{c}\text { Standardized } \\
\text { Coefficients }\end{array} \\
\text { Beta }\end{array}$} & \multirow{2}{*}{$\mathrm{t}$} & \multirow{2}{*}{ Sig. } \\
\hline & & B & $\begin{array}{l}\text { Std. } \\
\text { Error }\end{array}$ & & & \\
\hline \multirow{6}{*}{1} & (Constant) & -4.930 & 5.265 & & -.936 & .351 \\
\hline & Tangibility & .195 & .085 & .174 & 2.294 & .024 \\
\hline & Reliability & .131 & .117 & .122 & 1.115 & .268 \\
\hline & Responsiveness & -.005 & .093 & -.005 & -.059 & .953 \\
\hline & Assurance & .422 & .132 & .401 & 3.188 & .002 \\
\hline & Empathy & .266 & .116 & .244 & 2.298 & .024 \\
\hline
\end{tabular}

a. Dependent Variable: Patient Satisfaction

Partially, independent variables that are significantly related to patient satisfaction were tangibility, assurance and empathy. Reliability and responsiveness did not affect Telemedicine Application's patient satisfaction. With longdistance consultation, the patient could not see the doctor's face [19]. Hence the patient felt the doctor was incompetent, irresposible to their patients and unable to provide reliable consultation. This often results in patients to say their service quality of long-distance consultation was poor, because of their experience.

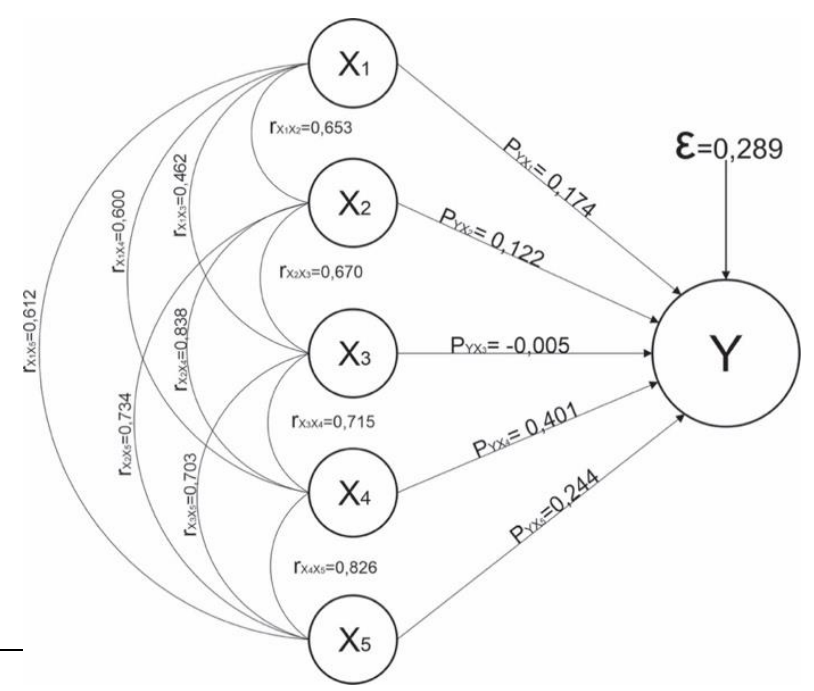

Fig. 2. Telemedicine Application's Pathway Analysis.

H2: There is an influence of service quality on face-toface consultation (conventional) patient satisfaction

TABLE 5: CONVENTIONAL's QUESTIONNAIRE DATA PROCESS RESUlt

\begin{tabular}{ccccc}
\multicolumn{4}{c}{ Model Summary } \\
\hline Model & $\mathrm{R}$ & R Square & $\begin{array}{c}\text { Adjusted R } \\
\text { Square }\end{array}$ & $\begin{array}{c}\text { Std. Error of the } \\
\text { Estimate }\end{array}$ \\
\hline 1 & $.894^{\mathrm{a}}$ & .799 & .789 & 6.76089 \\
\hline
\end{tabular}

a. Predictors: (Constant), Empathy, Tangibility, Reliability, Responsiveness, Assurance.

b. Dependent Variable: Patient Satisfaction.

\begin{tabular}{|c|c|c|c|c|c|c|}
\hline & \multicolumn{6}{|c|}{ ANOVA $^{a}$} \\
\hline & Model & $\begin{array}{c}\text { Sum of } \\
\text { Squares }\end{array}$ & df & Mean Square & $\mathrm{F}$ & Sig. \\
\hline \multirow{3}{*}{1} & Regression & 17112.290 & 5 & 3422.458 & & $.000^{\mathrm{b}}$ \\
\hline & Residual & 4296.710 & 94 & 45.710 & & \\
\hline & Total & 21409.000 & 99 & & & \\
\hline
\end{tabular}

a. Dependent Variable: Patient Satisfaction

b. Predictors: (Constant), Empathy, Tangibility, Reliability, Responsiveness, Assurance. 
Based on data processing, with significance $<0.05$ and $F$ calculation > F table then Hypothesis 2 can be accepted. There are other factors influencing patient satisfaction as much as $20.1 \%$. This corresponds to a study in a hospital in Iran that stated excellent service quality results in a positive impact on patient satisfaction [20]. Another study concluded that the most crucial determinant in patient satisfaction was excellent service quality [21].

\begin{tabular}{|c|c|c|c|c|c|}
\hline & & & Coeffic & ents $^{a}$ & \\
\hline \multirow[b]{2}{*}{ Model } & \multicolumn{2}{|c|}{$\begin{array}{l}\text { Unstandardized } \\
\text { Coefficients }\end{array}$} & $\begin{array}{c}\text { Standardized } \\
\text { Coefficients }\end{array}$ & \multirow{2}{*}{$\mathrm{t}$} & \multirow{2}{*}{ Sig. } \\
\hline & $\mathrm{B}$ & $\begin{array}{l}\text { Std. } \\
\text { Error }\end{array}$ & Beta & & \\
\hline 1 (Constant) & 6.629 & 4.343 & & 1.526 & .130 \\
\hline Tangibility & .075 & .076 & .075 & .990 & .325 \\
\hline Reliability & .247 & .090 & .228 & 2.745 & .007 \\
\hline Responsiveness & -.211 & .099 & -.177 & -2.128 & .036 \\
\hline Assurance & .613 & .105 & 607 & 5.824 & .000 \\
\hline Empathy & .196 & .103 & .200 & 1.904 & .060 \\
\hline
\end{tabular}

a. Dependent Variable: Patient Satisfaction

Partially, service quality dimensions that significantly influence patient satisfaction were reliability and assurance. The oher three variables (tangibility, responsiveness, and empathy) turn out to not be significantly related to patient satisfaction. This result does not correspond to Meesala \& Paul [22] study that stated only reliability and responsiveness influence patient satisfaction, while the other three dimensions did not.

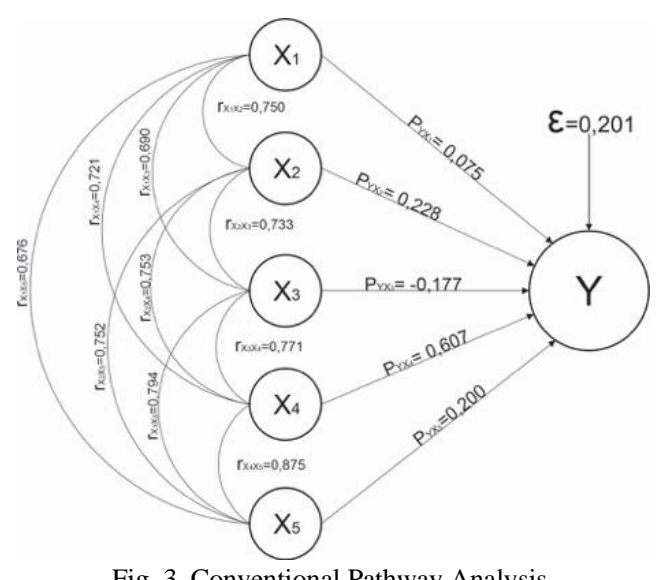

Fig. 3. Conventional Pathway Analysis.

H3: There is a significant difference between Telemedicine Application and face-to-face consultation patient satisfaction

Based on Wilcoxon test, Hypothesis 3 can be accepted because significance is $<0.05$. Based on the median of both satisfaction value, face-to-face consultation had higher satisfaction value than Telemedicine Application.

This result is certainly different from the previous study by Nordal et al [23], in Norway, that stated respondents were more satisfied with the video conferences because it reduced their waiting time. Another study conducted by Grant et al [24] in the United States also stated that research subjects were more satisfied with telemedicine. Also, research conducted by Polinski et al [25] in the United States showed $95 \%$ of patients were very satisfied with the quality of health services provided by telehealth and rated telehealth as better than or was good as conventional visits.
TABLE 7: PATIENT SATISFACTION DATA PROCESS Descriptive Statistics

\begin{tabular}{|c|c|c|c|c|c|}
\hline & $N$ & Mean & $\begin{array}{c}\text { Std. } \\
\text { Deviation }\end{array}$ & $\begin{array}{l}\text { Minimu } \\
\mathrm{m}\end{array}$ & $\begin{array}{l}\text { Maximu } \\
\mathrm{m}\end{array}$ \\
\hline \multirow{4}{*}{$\begin{array}{l}\text { Telemedicine } \\
\text { Application's } \\
\text { Patient } \\
\text { Satisfaction } \\
\text { Conventional's } \\
\text { Patient } \\
\text { Satisfaction } \\
\end{array}$} & 100 & 65.0500 & 16.02547 & 20.00 & 100.00 \\
\hline & 100 & 77.9000 & 14.70553 & 30.00 & 100.00 \\
\hline & \multicolumn{3}{|c|}{$\begin{array}{c}\text { Wilcoxon Signed Ranks Test } \\
\quad \text { Ranks } \\
\end{array}$} & & \\
\hline & & $\mathrm{N}$ & Mean Rank & \multicolumn{2}{|c|}{ Sum of Ranks } \\
\hline $\begin{array}{l}\text { Conventional's } \\
\text { Patient } \\
\text { Satisfaction }\end{array}$ & $\begin{array}{r}\text { Negative } \\
\text { Ranks }\end{array}$ & $22^{\mathrm{a}}$ & 36.64 & & 806.00 \\
\hline $\begin{array}{l}\text { Telemedicines } \\
\text { Application's } \\
\text { Patient }\end{array}$ & $\begin{array}{r}\text { Positive } \\
\text { Ranks }\end{array}$ & $67^{\mathrm{b}}$ & 47.75 & & 3199.00 \\
\hline & $\begin{array}{r}\text { Ties } \\
\text { Total }\end{array}$ & $\begin{array}{c}11^{\mathrm{c}} \\
100\end{array}$ & & & \\
\hline
\end{tabular}

a. Conventional's Patient Satisfaction < Telemedicine Application's Patient Satisfaction.

b. Conventional's Patient Satisfaction > Telemedicine Application's Patient Satisfaction.

c. Conventional's Patient Satisfaction = Telemedicine Application's Patient Satisfaction.

\begin{tabular}{rc} 
Test Statistics ${ }^{a}$ \\
\hline & $\begin{array}{c}\text { Conventional's Patient Satisfaction - } \\
\text { Telemedicine Application's Patient } \\
\text { Satisfaction }\end{array}$ \\
\hline $\mathrm{Z}$ & $-4.910 \mathrm{~b}$ \\
Asymp. Sig. (2-tailed) & .000 \\
\hline
\end{tabular}

a. Wilcoxon Signed Ranks Test.

b. Based on negative ranks.

Based on Wilcoxon test, Hypothesis 3 can be accepted because significance is $<0.05$. Based on the median of both satisfaction value, face-to-face consultation had higher satisfaction value than Telemedicine Application.

This result is certainly different from the previous study by Nordal et al [23], in Norway, that stated respondents were more satisfied with the video conferences because it reduced their waiting time. Another study conducted by Grant et al [24] in the United States also stated that research subjects were more satisfied with telemedicine. Also, research conducted by Polinski et al [25] in the United States showed $95 \%$ of patients were very satisfied with the quality of health services provided by telehealth and rated telehealth as better than or was good as conventional visits.

This might be due to the fact that telemedicine application is relatively new in Indonesia, so there are still many respondents who preferred to come to healthcare facilities rather than through applications. In addition, many respondents felt that the consultation time in the application was less (because in this case, doctors and patients could do other things besides consultation) so that the respondents' experience using the application was felt to be less satisfied.

\section{CONCLUSION AND SUGGESTION}

\section{A. Conclusion}

Based on the questionnaires filled out by respondents, more respondents agree and strongly agree that conventional service is better than Telemedicine Application's. As well as conventional's patient satisfaction had a higher agree and strongly agree percentage than Telemedicine Application's. 
Service quality significantly influenced patient satisfaction that had Telemedicine Application's consultation simultaneously. The reliability and responsiveness variables of Telemedicine Application did not influence patient satisfaction significantly. The most dominant variable that influenced Telemedicine Application's patient satisfaction was assurance with beta coefficient of 0.401 while the most uninfluential variable was responsiveness with beta coefficient -0.005 .

Service quality significantly influenced patient satisfaction that had conventional consultation simultaneously. In conventional service, tangibility, responsiveness and empathy were not significant influence of patient satisfaction. The most dominant variable that influence patient satisfaction was assurance with beta coefficient of 0.607 while the most uninfluential variable was responsiveness with beta coefficient -0.177 .

There is a significant difference between patient satisfaction who consulted through Telemedicine Application and face-to-face. The satisfaction of conventional consultation/face-to-face patients is higher than the satisfaction of Telemedicine Application patients.

\section{B. Suggestion}

Due to the limitations of the study, the factors affecting patient satisfaction in this study was service quality, which included tangibility, reliability, assurance, responsiveness, and empathy. While there are many other factors that affect patient satisfaction. Also, the use of questionnaires in this study is one of the limitations because the answers given by respondents sometimes do not match the truth.

Author suggests further research needs to be done in describing this path analysis model because the author found new results, namely responsiveness that does not affect patient satisfaction both Telemedicine Application and conventional. If, in the future, there will be researchers who are interested in researching using this model, it is expected to explore other variables because this research only looks at the service quality factor, whereas many other factors will influence patient satisfaction.

\section{REFERENCES}

[1] Silva, B. M., Rodrigues, J. J., de la Torre Díez, I., López-Coronado, M., \& Saleem, K. (2015). Mobile-health: A review of current state in 2015. Journal of Biomedical Informatics, 56, 265-272.

[2] Wallace, S., Clark, M., \& White, J. (2012). 'It's on my iPhone': attitudes to the use of mobile computing devices in medical education, a mixed-methods study. BMJ open, 2(4), e001099.

[3] Hilmy, S., \& Demi, S. (2019). Doctor at your Fingertips. Diakses melalui https://lup.lub.lu.se/studentpapers/search/publication/8981234.

[4] Santoso, B. S., Rahmah, M., Setiasari, T., \& Sularsih, P. (2015). Perkembangan Dan Masa Depan Telemedika Di Indonesia. National Coference on Information Technology and Technical enginee-ring (CITEE).

[5] Indonesia, MenKes. (2019). Peraturan Menteri Kesehatan Republik Indonesia Nomor 20 Tahun 2019 tentang Telemedicine. Jakarta: Menteri Kesehatan Indonesia.

[6] Nordal, E. J., Moseng, D., Kvammen, B., \& Løchen, M. L. (2001). A comparative study of teleconsultations versus face-to-face consultations. Journal of Telemedicine and Telecare, 7(5), 257-265.

[7] Grant, L. A., Rockwood, T., \& Stennes, L. (2015). Client satisfaction with telehealth services in home health care agencies. Journal of telemedicine and telecare, 21(2), 88-92.

[8] Polinski, J. M., Barker, T., Gagliano, N., Sussman, A., Brennan, T. A., \& Shrank, W. H. (2016). Patients' satisfaction with and preference for telehealth visits. Journal of general internal medicine, 31(3), 269-275.

[9] Konsil Kedokteran Indonesia. (2018). Kebijakan Kementrian Kesehatan Dalam Pengaturan Dokter \& Dokter Gigi di Era Global. Diakses

http://www.kki.go.id/assets/data/menu/Kemenkes_RI__Slamet_MEA_Makassar_23_April_18.pdf.

[10] Tjiptono, F., Chandra, G. (2016), Service, Quality dan Satisfaction. Yogyakarta: Penerbit Andi.

[11] Choudhury, K. (2013). Service quality and customers' purchase intentions: an empirical study of the Indian banking sector. International Journal of Bank Marketing, 31(7), 529-543.

[12] Nekoei-Moghadam, M., \& Amiresmaili, M. (2011). Hospital services quality assessment: Hospitals of Kerman University of Medical Sciences, as a tangible example of a developing country. International journal of health care quality assurance, 24(1), 57-66.

[13] Kansra, P., \& Jha, A. K. (2016). Measuring service quality in Indian hospitals: an analysis of SERVQUAL model. International Journal of Services and Operations Management, 24(1), 1.

[14] Ndubisi, N. O., \& Nataraajan, R. (2018). Customer satisfaction, Confucian dynamism, and long-term oriented marketing relationship: A threefold empirical analysis. Psychology \& Marketing, 35(6), 477 487.

[15] de Oña, J., de Oña, R., Eboli, L., Forciniti, C., \&amp; Mazzulla, G. (2016). Transit passengers' behavioural intentions: The Influence of Service Quality and Customer Satisfaction. Transportmetrica A: Transport Science, 12(5), 385-412.

[16] Dobrzykowski, D. D., Callaway, S. K. Vonderembse, M. A. (2015). Examining pathways from innovation orientation to patient satisfaction: A relational view of healthcare delivery. Decision Sciences, 46(5), 863-899.

[17] Wu, H. C., Li, T., \& Li, M. Y. (2016). A study of behavioral intentions, patient satisfaction, perceived value, patient trust and experiential quality for medical tourists. Journal of Quality Assurance in Hospitality \& Tourism, 17(2), 114-150.

[18] Garcia, R., Olayele, A., \& Han, W. (2017). Defining dimensions of patient satisfaction with telemedicine: An analysis of existing measurement instruments. In Proceedings of the 50th Hawaii international conference on system sciences.

[19] Lu, W., \& Sun, D. (2018). The Patient's Satisfaction and Influencing Factors in Remote Consultation. 2018 2nd International Conference on Social Sciences, Arts and Humanities (SSAH 2018).

[20] Pouragha, B., \& Zarei, E. (2016). The effect of outpatient service quality on patient satisfaction in teaching hospitals in Iran. Materia socio-medica, 28(1), 21.

[21] Batbaatar, E., Dorjdagva, J., Luvsannyam, A., Savino, M. M., \& Amenta, P. (2016). Determinants of patient satisfaction: a systematic review. Perspectives in public health, 137(2), 89-101.

[22] Meesala, A., \& Paul, J. (2018). Service quality, consumer satisfaction and loyalty in hospitals: Thinking for the future. Journal of Retailing and Consumer Services, 40, 261-269.

[23] Nordal, E. J., Moseng, D., Kvammen, B., \& Løchen, M. L. (2001). A comparative study of teleconsultations versus face-to-face consultations. Journal of Telemedicine and Telecare, 7(5), 257-265.

[24] Grant, L. A., Rockwood, T., \& Stennes, L. (2015). Client satisfaction with telehealth services in home health care agencies. Journal of telemedicine and telecare, 21(2), 88-92.

[25] Polinski, J. M., Barker, T., Gagliano, N., Sussman, A., Brennan, T. A., \& Shrank, W. H. (2016). Patients' satisfaction with and preference for telehealth visits. Journal of general internal medicine, 31(3), 269-275.

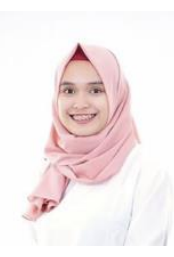

Tamara Tantarto obtained a bachelor's degree (Majoring in Medicine) from Padjajaran University, Indonesia in 2015. She continued to study Management at Padjajaran University, Indonesia and received a master's degree in 2019 with a concentration in Hospital Management.

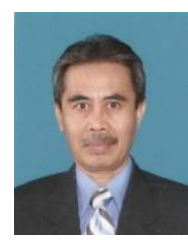

Dadang Kusnadi obtained his diploma from the Academy of Anesthetic Care (AKNES) RSHS Bandung, Indonesia. After that, he continued his undergraduate education at STIA-LAN-RI Bandung, Indonesia. Then he got a MARS degree from the Faculty of Public Health, University of Indonesia, Jakarta, Indonesia. His last education was a doctoral education at the Social FISIP Admin.Keb.Publik Padjajaran University, Indonesia. 
Hadyana Sukandar obtained his bachelor's degree (Statistics Department) from Padjajaran University, Indonesia in 1980. He continued his studies at the University of London to obtain an MSc in Medical Demography from London School of Hygiene and Tropical Medicine in 1990. And in 2006, he holds a Doctorate in Epidemiology Graduted from the Faculty of Public Health, University of Indonesia. Currently, he became a lecture Padjajaran University, Indonesia. 